\title{
Erratum zu: Selbsterfüllende Prophezeiungen in der Schule
}

\section{Erratum zu: \\ G. Lorenz, Selbsterfüllende Prophezeiungen in der Schule, https://doi.org/10.1007/978-3-658-19881-7}

Vollständig überarbeitetes und ergänztes Literaturverzeichnis.

Die aktualisierte Version des Buches finden Sie unter https://doi.org/10.1007/978-3-658-19881-7 